Łukasz Pyfel

Uniwersytet Łódzki

https://doi.org/10.18778/1733-8069.11.1.05

\title{
Badacz jakościowy w świątyni liczb i pieniądza - wykorzystanie metod jakościowych w badaniu
} rynków finansowych

Abstrakt Celem artykułu jest pokazanie, w jaki sposób metody jakościowe mogą przyczynić się do lepszego zrozumienia mechanizmów funkcjonowania rynków finansowych. We wprowadzeniu krótko omówione zostały procesy wzrostu znaczenia sektora finansów w gospodarce i życiu społecznym oraz rozwój rynków finansowych i ilościowych metod ich badania. Jako ilustracje przydatności metod jakościowych w analizie rynków finansowych podano przykłady z trzech obszarów: 1) performatywności ekonomii finansowej, 2) badań organizacji działających na rynkach finansowych oraz 3) badań zagadnień związanych z komputeryzacją i automatyzacją rynków finansowych. Obszary te powinny stanowić temat dalszych eksploracji prowadzonych przez badaczy jakościowych. W części podsumowującej artykuł umieszczono również przykłady oraz możliwe kierunki praktycznego zastosowania wiedzy będącej wynikiem badań jakościowych.

Słowa kluczowe socjologia finansów, metody jakościowe, rynki finansowe, performatywność ekonomii, socjologia organizacji

Lukasz Pyfel, doktorant w Katedrze Socjologii Organizacji i Zarządzania Instytutu Socjologii Uniwersytetu Łódzkiego. Absolwent studiów podyplomowych Metody ilościowe w analizie rynków finansowych w Szkole Głównej Handlowej. Jego zainteresowania naukowe koncentrują się wokół socjologii finansów oraz metodologii badań społecznych.

\section{Adres kontaktowy:}

Katedra Socjologii Organizacji i Zarządzania

Instytut Socjologii Uniwersytetu Łódzkiego

ul. Rewolucji 1905 r. 41, 90-214 Łódź

e-mail: lukaszpyfel@gmail.com
Pynki finansowe ${ }^{1}$, co unaocznił ostatni kryKzys, stały się jednym z najważniejszych elementów światowej gospodarki. W ostatnich dekadach znacząco wzrosły obroty oraz poziom skomplikowania wykorzystywanych instrumentów finansowych. Ponadto dzięki rozwojowi nowoczesnych technologii i mniejszym barierom wejścia na rynek finansowy inwestowanie staje

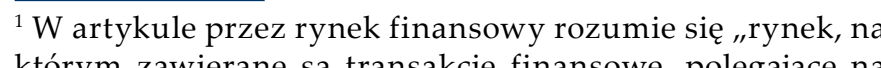
ktorym zawierane są transakcje finansowe, polegajace na
sprzedaży i zakupie instrumentów finansowych" (Jajuga sprzedazy i zakupie instrumentów finansowych" (Jajuga,
Jajuga 2002: 17), który dzieli się na cztery główne segmenty pieniężny, kapitałowy, instrumentów pochodnych i walutowy. się dostępne dla coraz większej liczby osób. Rynki finansowe ze względu na swoją istotność dla współczesnego świata z pewnością zasługują na uwagę badaczy jakościowych. Może się jednak nasunąć pewna wątpliwość - czy badacze jakościowi są w stanie wnieść coś nowego i wartościowego $\mathrm{w}$ rozumienie mechanizmów funkcjonowania rynków finansowych? Celem niniejszego artykułu jest pokazanie, w jaki sposób jakościowe nauki społeczne mogą przyczynić się do lepszego zrozumienia rynków finansowych oraz dostarczyć wskazówek dotyczących zarządzania nimi i ich reformowania. Artykuł stanowić ma wprowadzenie do omawianej problematyki i nie skupia się na żadnej konkretnej metodologii czy podejściu teoretycznym. W pierwszej części artykułu zostało krótko opisane znaczenie, jakie mają rynki finansowe w dzisiejszym świecie, rozwój tych rynków oraz metody wykorzystywane przy ich badaniu. Druga, główna część artykułu, przedstawia przykłady owocnego zastosowania metod jakościowych w badaniach rynków finansowych w podziale na trzy główne obszary tematyczne: 1) społeczną historię ekonomii finansowej i performatywność nauki o finansach, 2) badania organizacji działających na rynkach finansowych, 3) anonimowość transakcji online lub wręcz handel dokonywany przez komputery. Ze względu na często interdyscyplinarny charakter tych badań przywołane zostaną przykłady nie tylko z socjologii, ale również z innych dziedzin nauki, takich jak antropologia czy zarządzanie. W trzeciej, ostatniej części umieszczone zostało podsumowanie, wnioski oraz możliwe zastosowania wyników badań jakościowych w praktyce życia gospodarczego.
Rozwój rynków finansowych i metod ich badania

Wzrost znaczenia rynków finansowych jest najlepiej widoczny (i również najszerzej obecny w świadomości społecznej) w kontekście wzrostu wartości sektora finansowego ${ }^{2} \mathrm{w}$ porównaniu z gospodarką realną. Interesujących danych na ten temat dostarczyła analiza Thomasa Philippona (2011), który bazując na danych z różnorodnych źródeł, pokazał zmiany znaczenia sektora finansowego w gospodarce Stanów Zjednoczonych. Nie zagłębiając się w kwestie metodologiczne, na wykresie wyraźnie widać, że od lat powojennych mieliśmy do czynienia z wyraźnym wzrostem znaczenia sektora finansowego. W 1950 roku udział sektora finansowego $\mathrm{w}$ gospodarce Stanów Zjednoczonych wynosił około $4 \%$, powoli wzrastał do $5 \%$ w roku 1990, żeby następnie gwałtownie wzrosnąć do prawie $9 \%$ w roku 2010. Warto też zauważyć, że z jego dynamicznym wzrostem mieliśmy również do czynienia w czasach poprzedzających Wielki Kryzys.

Jednak wzrost znaczenia rynków finansowych zwany w literaturze przedmiotu "finansjalizacja”" (financialization) nie przejawia się jedynie we wzroście ilościowym tego sektora, ale również, lub może przede wszystkim, w postępującym procesie nakładania na świat zewnętrzny reguł ze świata finansów. Jak to ujął Manuel Aalbers, „zasady i logika Wall Street coraz bardziej stają się logiką i zasadami

${ }^{2}$ Należy poczynić zastrzeżenie, że dane te odnoszą się do całego sektora finansowego, czyli obejmują również na przykład
bankowość detaliczna, korporacyjną oraz ubezpieczenia, a nie
tylko do instytucji działających bezpośrednio na rynkach fitylko do instytucji działających bezpośrednio na rynkach fi-
nansowych. 
Rysunek 1. Udział sektora finansów w dochodzie Stanów Zjednoczonych w latach 1870-2009 z pominięciem przemysłu obronnego i rolnictwa.

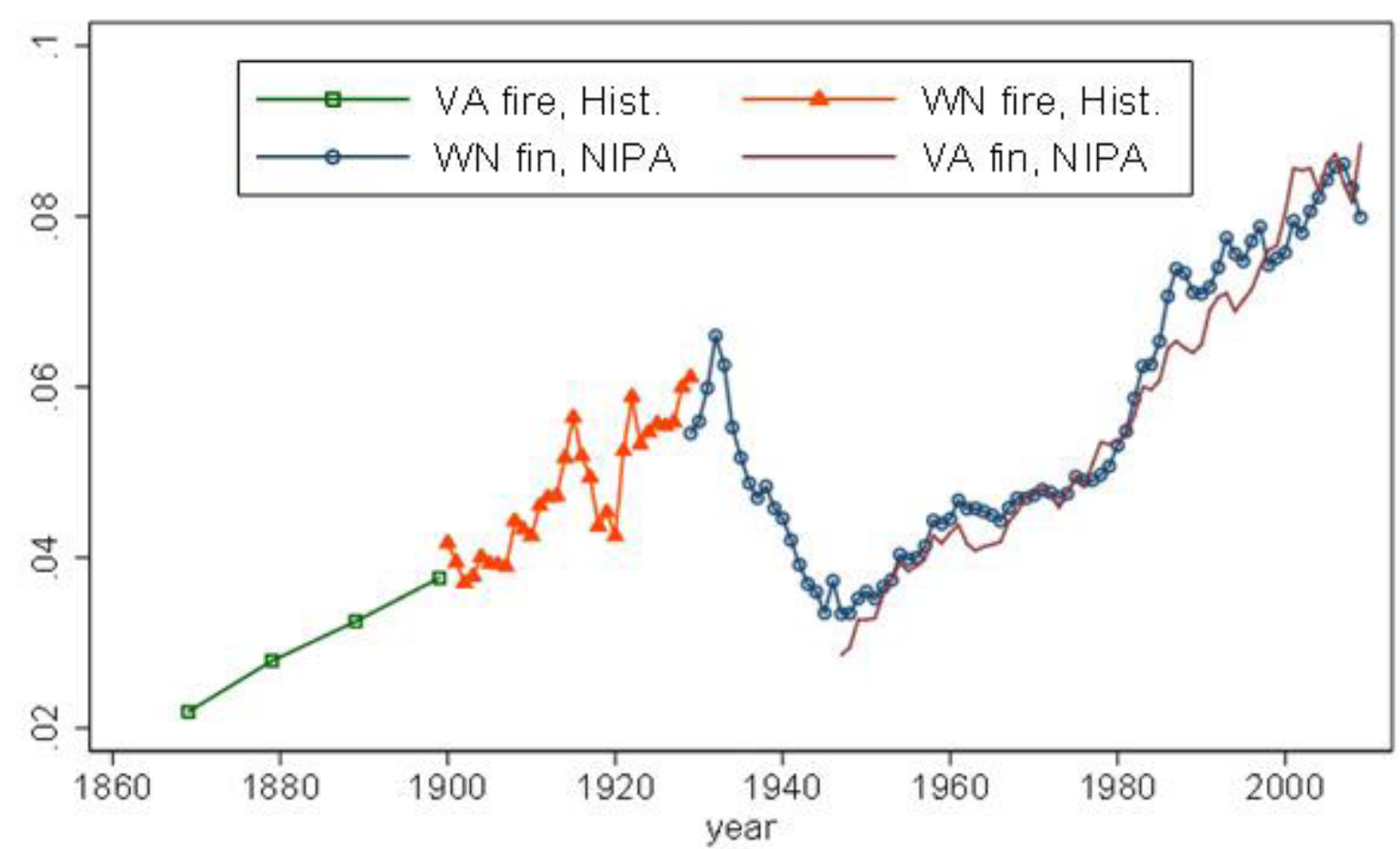

VA - wartość dodana, WN - wynagrodzenie pracowników, fire - finanse, ubezpieczenia i nieruchomości, fin - finanse i ubezpieczenia, Hist. - źródłem danych jest Historical Statistics of United States, NIPA - źródłem danych jest Bureau of Economic Analysis. Źródto: Philippon (2011:3).

świata poza Wall Street" (2008: 149 [tłum. własne]). Przy czym należy zaznaczyć, że procesy finansjalizacji zachodzą nie tylko w gospodarce jako związane z problematyką zarządzania korporacjami i wyznaczania im celów (zob. np. Ho 2009), ale wpływają też bezpośrednio na życie jednostki, co można określić mianem finansjalizacji życia codziennego (Martin 2002). Najlepszymi przykładami takiej finansjalizacji są: traktowanie domu jako inwestycji, konieczność rozumienia dziedziny finansów (financial literacy) przez obywateli kapitalistycznego społeczeństwa (Erturk i in. 2007) czy przenoszenie coraz większej odpowiedzialności za zabezpiecze- nia głównym, a może i jedynym, celem jest zysk. Uczestnicy tych rynków, szczególnie profesjonalni, powinni zatem być całkowicie racjonalni. Gdzie można byłoby szukać homo oeconomicus, jeśli nie na rynkach finansowych? A do badania i rozumienia homo oeconomicus teorie ekonomiczne mogą okazać się całkowicie wystarczające. Kiedyś uczestnicy rynków finansowych zawierali transakcje osobiście, więc można było łatwo dostrzec jakieś pole do wykorzystania przez badania jakościowe. Później przyszedł czas komputeryzacji i transakcje zaczęły być zawierane za pośrednictwem systemów komputerowych pomiędzy anonimowymi dla siebie partnerami. Wreszcie, coraz częściej transakcje zawierane są pomiędzy dwoma komputerami posługującymi się specjalnymi algorytmami - komputery stały się w części przypadków nie tylko pośrednikami, ale i wykonawcami. Przy badaniu takich racjonalnych, dążących do optymalizacji zysku finansowego, zatomizowanych, anonimowych aktorów (którzy w dodatku coraz częściej nie są ludźmi) może wydawać się, że perspektywa socjologii jakościowej nie jest w stanie wnieść nic nowego i ciekawego do wiedzy o rynkach finansowych ${ }^{3}$. Ponadto rynki finansowe są świątynią liczb. Dane ilościowe są dla badaczy łatwiej lub trudniej dostępne, ale są zapisywane na poziomie pojedynczej transakcji. Ta olbrzymia liczba danych finansowych jest nieustannie analizowana przy pomocy coraz nowocześniejszych metod ilościowych. Po pierwsze, te dane są analizowane za pomocą tradycyjnych technik ekonometrycznych (zob. np. Starzeński

${ }^{3} \mathrm{~W}$ tym miejscu należy również wspomnieć o rozwijających sie kierunkach $\mathrm{w}$ ekonomii, które badaja mn oblicze aktorów rynków finansowych, czyli o finansach behawioralnych (zob. np. Zielonka 2003) czy neurofinansach (zob. np. Sapra, Zak 2008).
2011) czy technik data mining (zob. np. Kovalerchuk, Vityaev 2000). Przy analizach dotyczących rynków finansowych wykorzystuje się również tak zwane big data, czego przykładem jest firma AmalgaMood (amalgamood.com), która oferuje analizę nastrojów inwestorów na podstawie zautomatyzowanej analizy wpisów w mediach społecznościowych, forach i blogach. Abstrahując od technik analizy, należy zaznaczyć również, że ze względu na możliwości finansowe firm inwestycyjnych przy analizie rynków finansowych pracują często najtęższe umysły nauk ścisłych (Ho 2009; Taleb 2010). Zatem przy tak dużej dostępności danych ilościowych, narzędzi i technik analitycznych oraz najwyższej klasy analityków ilościowych może wydawać się, że wykorzystanie metod jakościowych nie wniesie nic nowego do rozumienia rynków finansowych.

\section{Przykłady zastosowania metod jakościowych w badaniach rynków finansowych}

Jednak wbrew powyżej opisanym wątpliwościom, socjologia finansów, w której bardzo często podstawą są badania jakościowe, jest dynamicznie rozwijającą się dziedziną, o czym świadczy wiele ciekawych badań i publikacji (zob. np. Abolafia 1996; Carruthers, Stinchcombe 1999; Smith 1999; Knorr-Cetina, Preda 2005; 2013; MacKenzie 2006; Zaloom 2006; MacKenzie, Muniesa, Siu 2007; Ho 2009).

Historia społeczna i performatywność ekonomii finansowej

Jednym z najbardziej znanych przykładów badan zdziedziny socjologii finansów są badania dotyczące 
historii ekonomii finansowej i wpływu tej nauki na rozwój rynków finansowych (MacKenzie 2006). Swoje badania Donald MacKenzie oparł na kilkudziesięciu wywiadach indywidualnych z kluczowymi ekonomistami i praktykami rynków finansowych ${ }^{4}$. Realizacja tych wywiadów, wraz z przeglądem danych zastanych (analiza artykułów i archiwów naukowych, materiałów prasowych oraz literatury dotyczącej historii rynków finansowych), pozwoliła autorowi na opisanie społecznych i organizacyjnych uwarunkowań rozwoju ekonomii finansowej.

Zgodnie z podręcznikami finansów, do lat pięćdziesiątych finanse były nauką opisową, a dopiero później zaczęły stawać się „nauką analityczną, wykorzystującą precyzyjne metody ilościowe, nierzadko korzystającą z komputera" (Jajuga, Jajuga 2002: 13) ${ }^{5}$. Na podstawie swoich badań i wcześniejszych doświadczeń socjologa badającego rozwój nauki i technologii MacKenzie opisał historię rozwoju nauki o finansach jako podobną do rozwoju technologicznego, a nie reprezentującą linearny i kumulatywny model rozwoju nauki. Początkowy sukces jakiejś technologii powoduje nakładanie na nią ulepszeń oraz jej dalszy intensywny rozwój.

${ }^{4}$ Wśród badanych (rozmówców) znaleźli się między innymi: Robert C. Merton, Milton Friedman, Harry Markowitz, Myron S. Scholes, Paul Samuelson, Eugene Fama, Merton Mil-
ler, Franco Modigliani, William Sharpe, Benoit Mandelbrot czy Nassim Taleb.

Rozdźwięk pomiędzy starą a nową metodą badań ekonomii finansowej dobrze pokazuje uwaga, jaką w 1954 roku dostał Harry Markowitz od Miltona Friedmana podczas obrony swojej pracy doktorskiej: „[n]o dobrze Harry. Przeczytałem
twoja dysertacie i nie znalazłem żadnych błedów w matetwoja dysertacje i nie znalaztem zadnych blędow $w$ mateprzyznać doktoratu z ekonomii za dysertacje, która nie jest ekonomiczna" (fragment transkrypcji wywiadu z Markowitzem [MacKenzie 2006: 50 [tłum. własne]). Markowitz i tak otrzymał doktorat za tę prace.
Po pewnym czasie technologia, która wygrywała na początku, bardzo mocno prześciga technologie z nią rywalizujące, nawet jeśli później okazuje się nie być optymalną̧ . Taki kaskadowy rozwój miał również charakteryzować ekonomię finansową. Najważniejsi ekonomiści finansowi byli ze sobą powiązani, a prace jednych były oparte na pracach ich poprzedników. Bardzo duży wpływ na rozwój teorii wywarła też akademizacja szkół biznesowych - dla naukowców z dziedziny finansów najważniejsze stało się uznanie w oczach świata akademickiego, a nie rynku i praktyków. Do zdobycia takiego uznania kluczowe było przygotowanie spójnych, innowacyjnych i niesprawiających trudności modeli analitycznych. Koniecznościa było również publikowanie, co przyczyniło się do upowszechnienia modeli akademików (przykład modelu Blacka-Scholesa), podczas gdy część modeli wykorzystywanych przez praktyków nie była publikowana ani dostępna dla szerszego grona odbiorców. Ponadto po umocnieniu się ekonomii finansowej jako nauki akademickiej, okazało sie ważne, aby proponowane rozwiązania pasowały do dotychczasowej teorii, szczególnie do hipotezy rynku efektywnego. Może to tłumaczyć, dlaczego prace Daniela Kahnemana i Amosa Tverskiego (jedni z najwybitniejszych przedstawicieli ekonomii behawioralnej) oraz Edwarda Thorpe'a (matematyk, który pokazał, jak pokonać kasyno oraz jak sam twierdził, rynek) długo nie mogły przebić się do głównego nurtu ekonomii. Wspomniane

${ }^{{ }^{6} \text { Najłatwiejszym do dostrzeżenia przykładem takiej technolo- }}$ na do pisania na komputerze, dzieki temu, iż wcześniej jak optymalna przy starszych maszynach do pisania zdobyta bardzo dużą popularność, do dzisiaj jest powszechnie stosowanym światowym standardem (MacKenzie 2009). wyżej procesy MacKenzie pokazał za pomocą opisu historii rozwoju najważniejszych teorii ekonomii finansowej, uwzględniając przy tym biografie ich autorów oraz uwarunkowania organizacyjne ich powstawania.

Jednak największy wkład omawianej książki MacKenziego stanowiło opisanie performatywności ekonomii finansowej. Pojęcie performatywności ${ }^{7}$ zostało wprowadzone do socjologii ekonomicznej przez Michela Callona, który we wstępie do Laws of the Markets (1998) zaznaczał, że podejście wielu socjologów ekonomicznych do kwestii ekonomii i gospodarki jest niewystarczające. W języku angielskim istnieje rozróżnienie na ekonomię (economics) i gospodarkę (economy) oraz rynku jako czegoś abstrakcyjnego (market) i rynku jako miejsca (marketplace), co wskazuje na rozróżnienie pomiędzy teorią i praktyką. Obecna ekonomia jako nauka całkowicie abstrahuje od rynku jako czegoś materialnego. Według Callona istnieje zatem pokusa, której ulegało wielu socjologów ekonomicznych, żeby stwierdzić, że ekonomia jako nauka zbyt daleko odeszła od gospodarki (obiektu nauki) i należy po prostu skierować ekonomię z powrotem w kierunku rynku jako miejsca. Callon postuluje inne podejście. Z jego punktu widzenia „ekonomia, w szerokim tego słowa znaczeniu, tworzy (perform), kształtuje i nadaje formę (format) gospodarce" (Callon 1998: 2 [tłum. własne]). Zgodnie z tezami Callona, celem badań powinno być zatem uchwycenie subtelnych relacji pomiędzy ekonomią a gospodarką oraz wpływu ekonomii na życie gospodarcze. Tak postawiony cel $\mathrm{w}$ kontekście ekonomii finanso-

${ }_{7}$ Samo pojęcie performatywności zostało ukute przez filozofa Johna Austina (1962). wej i rynków finansowych wydawały się bardzo dobrze spełniać omawiane badania MacKenziego (2006), który opisał, jak od lat siedemdziesiątych naukowcy zajmujący się finansami, dzięki łatwe$\mathrm{mu}$ dostępowi do danych, wsparciu instytucjonalnemu i wzrostowi znaczenia sektora finansów, mieli coraz mocniejszą pozycję nie tylko w świecie nauki. Pomimo początkowych dużych oporów ze strony praktyków ekonomia finansowa była coraz częściej wykorzystywana przez osoby i instytucje zajmujące się rynkiem finansowym oraz była stopniowo włączana $\mathrm{w}$ infrastrukturę rynków finansowych na trzech płaszczyznach - technicznej, językowej oraz legitymizującej. Pierwsza z tych płaszczyzn, techniczna, polega na włączaniu modeli $\mathrm{w}$ infrastrukturę rynku (np. oprogramowanie wyceniające instrumenty pochodne opiera się na modelach bazujących na filozofii modelu Blacka-Scholesa). Druga płaszczyzna, językowa, ma miejsce w przypadku włączania języka teorii do codziennego języka praktyków rynku (np. do codziennego użytku wszedł termin „wskaźnik beta” Sharpe'a). Z kolei przy legitymizacji chodzi o uwiarygodnienie rynków finansowych przez autorytet nauki. Ta ostatnia z płaszczyzn jest szczególnie istotna, ponieważ inwestowanie na rynkach finansowych od ich początków postrzegane bywało jako podobne do hazardu (Preda 2009a). Takie włączanie ekonomii finansowej w infrastrukturę rynków finansowych powodowało, że rzeczywistość zaczynała przypominać swój obraz z teorii (performatywność Barnesa), ale niekiedy też prowadziło do oddalania się rzeczywistości od jej teoretycznego obrazu (kontrperformatywność). Najlepszym przykładem performatywności ekonomii finansowej 
jest model wyceny opcji ${ }^{8}$ Fischera Blacka i Myrona Scholesa (MacKenzie, Millo 2003; MacKenzie 2006). Model ten był elegancki, zwięzły i możliwy $\mathrm{w}$ zastosowaniu praktycznym. Autorzy tego modelu otrzymali Nagrodę Nobla, a sam model pozwolił na legitymizację handlu instrumentami pochodnymi, uwalniając je od piętna hazardu, co umożliwiło gwałtowny rozwój rynku derywatów. Model wyceny opcji był również włączany $w$ infrastrukturę rynku za pośrednictwem coraz bardziej zaawansowanych narzędzi (np. arkusze wyceny opcji, a później oprogramowanie). Brak jednoznacznych dowodów na potwierdzenie tej tezy, ale część testów ekonometrycznych wskazuje, że wprowadzenie modelu wyceny opcji najpierw doprowadziło do zbliżenia się rzeczywistości do wyników teoretycznych, ale po kryzysie w 1987 roku wyniki rzeczywiste zaczęły bardziej odstawać od modelu (MacKenzie 2006).

Powyżej opisane badania są nie tylko bardzo dobrym przykładem na owocne zastosowanie metod jakościowych w analizach rynków finansowych, ale również wskazują na obszar, który powinien być przedmiotem dalszej eksploracji badaczy jakościowych. Badając performatywność ekonomii finansowej, należy zwrócić się ku socjologii materialnej i uwzględnić $\mathrm{w}$ analizie między innymi takie czynniki jak narzędzia, modele, komputery czy materialne nośniki wiedzy (MacKenzie 2009). Włączenie tych czynników do analizy pozwala na uchwycenie sposobów, w jakie teorie ekonomiczne wpływają na czowi prawo do zakupu lub sprzedazy innego instrumentu Posiadanie opcji daje prawo, a nie zobowiązanie" (Jajuga, Jajuga 2002: 181). codzienne praktyki uczestników rynku. Takie podejście jest również zbieżne z będącymi inspiracją dla części przedstawicieli socjologii finansów teorią aktora-sieci (actor-network theory - ANT), społecznymi badaniami nad nauką (social studies of science) oraz etnografią laboratorium (Arminem 2010).

\section{Organizacje działające na rynkach finansowych}

Obok badań związanych z performatywnością ekonomii bardzo istotną dziedziną socjologii i antropologii finansów są badania najważniejszych aktorów rynków finansowych, czyli instytucji, takich jak banki i firmy inwestycyjne. Istnieje wiele przykładów badań jakościowych dotyczących instytucji rynku finansowego (zob. np. Abolafia 1996; Zaloom 2006; MacKenzie 2009; Tarim 2012), ale ze względu na cel i objętość artykułu poniżej krótko opisane zostały jedynie dwa takie badania.

Bardzo ciekawym przykładem badań jakościowych dotyczących instytucji rynku finansowego są badania antropolożki Karen Ho (2009), które koncentrują się na bankach inwestycyjnych z Wall Street. Karen Ho podczas studiów na Uniwersytecie w Princeton wzięła rok urlopu dziekańskiego i pracowała przez ten czas $\mathrm{w}$ jednym $\mathrm{z}$ banków inwestycyjnych w komórce zajmującej się konsultingiem wewnętrznym. Po tym jak została zwolniona $\mathrm{z}$ banku, rozpoczęła właściwe badania, w których podjęła tematykę habitusu pracowników instytucji Wall Street oraz kultury organizacyjnej ${ }^{9}$ nowojor-

${ }^{9}$ Ho przyjęła za Eriką Schoenberger szeroką definicję kultury korporacyinej jako naturalnie $i$ gteboko dinice ku $\mathrm{w}$ to, co robimy oraz w jakich społecznych i historycznych warunkach myślimy $i$ jak rozumiemy to, co robimy, jak myślimy o sobie w tym kontekście. To [kultura organizacyjna skich banków inwestycyjnych. Sposób prowadzenia jej badań zbliżony był do podejścia określanego mianem „polimorficznego zaangażowania” (polymorphous engagement) (Ho 2009 za Gusterson 1997). Ze względu na trudność (czasem wręcz niemożliwość) prowadzenia obserwacji uczestniczącej $w$ takich miejscach jak banki inwestycyjne konieczne jest wyjście poza tę podstawową technikę etnografii i korzystanie z wielu źródeł, używając różnorodnych technik. W przypadku Ho obok obserwacji uczestniczącej były to przede wszystkim wywiady, shadowing, uczestnictwo w branżowych konferencjach, wydarzeniach networkingowych, rekrutacyjnych i imprezach nieformalnych.

Tak prowadzone badania pozwoliły Ho na odpowiedzenie na nurtujące ją pytania badawcze. Już sam proces rekrutacji do banków inwestycyjnych, prowadzony jedynie na najlepszych uniwersytetach, świadczy o hiperelitarności pracy na Wall Street - praca tam zarezerwowana miała być jedynie dla najmądrzejszych. Następnie w tych firmach obok elitarności pojawia się etos ciężkiej pracy, często po ponad 100 godzin w tygodniu. W firmach inwestycyjnych bardzo widoczna okazała się ważność statusu w organizacji oraz wiążąca się z tym segregacja, również przestrzenna, różnych grup pracowników. Przy pomocy analizy historycznej Ho opisała też bardzo ważny proces - $\mathrm{w}$ korporacjach za zdecydowanie najważniejszy cel zaczęła być uznawana wartość dla akcjonariuszy (shareholder value). Wcześniej korporacje w Stanach Zjednoczonych

przyp. ŁP] obejmuje istotne praktyki, relacje społeczne oraz sposoby myslenia. Kultura jednoczessnie produkuje te
rzeczy i jest ich produktem w złożonym (...) procesie historycznym" (Ho 2009: 173 za Schoenberger 1997: 120 [tłum. własne]). postrzegane były raczej przez pryzmat korzyści, jakie przynosiły innym interesariuszom, czyli przede wszystkim pracownikom i klientom. Kolejnymi ważnymi aspektami Wall Street opisanymi przez Ho są płynność i krótkoterminowe myślenie oraz wynikająca $\mathrm{z}$ tego strategia braku strategii. Pracownicy banków inwestycyjnych często są zwalniani ${ }^{10}$ lub sami zmieniają pracę z powodu lepszych ofert, a jedyną relacją wiążącą ich $\mathrm{z}$ pracodawcą jest relacja finansowa. Ponadto pracownicy wynagradzani są za krótkoterminowe zyski i otrzymują prowizje od transakcji. Brak faktycznej długoterminowej strategii i duża elastyczność zatrudniania pozwalają na dopasowywanie firmy do zmieniającego się rynku. Na to wszystko nakłada się hipoteza Ho, że pracownicy banków inwestycyjnych nie postrzegają siebie jako poddających się siłom rynku, lecz jako emanację rynku. Omówione wyżej charakterystyki banków inwestycyjnych przyczyniają się do powstawania nawracających kryzysów finansowych oraz do tego, że normy z bankowości inwestycyjnej zaczynają być w coraz większym stopniu nakładane na korporacje, czyli coraz częściej zaczyna liczyć się jedynie zysk, a przekonanie, iż firmy powinny być $w$ jak największym stopniu pozbawione stałych kosztów, w tym etatowych pracowników, staje się coraz powszechniejsze.

Drugim interesującym przykładem są badania jakościowe przeprowadzone $\mathrm{w}$ działach ryzyka dwóch międzynarodowych banków (Hall, Mikes, Millo $\mathrm{w}$ druku). Badania dotyczyły przede wszystkim tego, w jaki sposób w skomplikowanej rzeczywistości organizacyjnej eksperci mogą zyskiwać wpływ na za-

${ }^{10}$ Ho pisze wręcz o „bulimicznej” kulturze zatrudniani i zwalniania pracowników w firmach inwestycyjnych. 
rządzających. W ramach badań autorzy w każdym z banków przeprowadzili semistrukturyzowane wywiady indywidualne z pracownikami, uzupełniającje analizą dokumentów wewnętrznych. Po uprzednim przeanalizowaniu tych dwóch banków niezależnie, przy pomocy analizy porównawczej zostały określone cztery główne umiejętności, które pozwalają na osiągnięcie przez ekspertów wpływu na zarządzających. Pierwszą z nich jest umiejętność współpracy z osobami z innych działów i nawiązywanie osobistych relacji. Korzystanie z tej umiejętności pozwala na poznanie perspektywy innych komórek organizacyjnych. Drugą kluczową umiejętnością jest umiejętność wytyczania nowych ścieżek, czyli sposobów wykorzystywania swojej wiedzy eksperckiej w nowych obszarach. Trzecią $\mathrm{z}$ umiejętności jest przygotowywanie narzędzi, które pomagałyby w przekazywaniu wiedzy eksperckiej, a czwartą tłumaczenie wiedzy dotyczącej tych narzędzi ich odbiorcom (Hall, Mikes, Millo w druku). To badanie na temat wpływu w organizacji jest bardzo ważne dla tematyki rynków finansowych, ponieważ silniejsza pozycja specjalistów od ryzyka w danej organizacji może przyczynić się do jej większej odporności na kryzysy, co wydaje się być potwierdzane przez zdarzenia mające miejsce podczas ostatniego kryzysu finansowego.

Dwa powyższe przykłady pokazuja, że badania jakościowe mogą dostarczyć wartościowej wiedzy dotyczącej działania instytucji będących najważniejszymi aktorami rynków finansowych. Nie powinno to dziwić ze względu na fakt, że metody jakościowe bardzo dobrze nadają się do badania rzeczywistości organizacyjnej, pozwalając poznać perspektywę jej uczestników (Konecki 2006). Problemem pozostaje jednak trudność dostępu badaczy do instytucji rynku finan- sowego, szczególnie w przypadku chęci wykorzystania techniki obserwacji uczestniczącej. Niekiedy rozwiązaniem tego problemu jest podjęcie przez badacza pracy w takich firmach (Zaloom 2006; Ho 2009) lub oparcie się przede wszystkim na innych niż obserwacja uczestnicząca metodach badań jakościowych.

\section{Komputer jako pośrednik lub partner interakcji}

Trzecim z omawianych przedmiotów zainteresowania badaczy społecznych jest wpływ komputeryzacji rynków finansowych na społeczną organizację rynku i jego aktorów. Jak zostało wcześniej wspomniane, na skutek zachodzących procesów automatyzacji i komputeryzacji obecnie większość transakcji zawierana jest za pośrednictwem systemów komputerowych pomiędzy anonimowymi dla siebie partnerami. Takie zmiany wpływają oczywiście na społeczną organizację rynków finansowych (Zaloom 2006) i mogą być ciekawym przedmiotem badań socjologii materialnej. Jednak jak postaram się pokazać, aktorzy rynków finansowych wciąż traktują transakcje, pomimo ich zapośredniczenia przez systemu komputerowe i anonimowości, jako interakcje z inny$\mathrm{mi}$, a dane rynkowe jako opisujące postawy innych uczestników rynku.

Pierwszym z takich przykładów jest badanie Alexa Predy (2009b), który zajmował się inwestorami nieinstytucjonalnymi. W ramach swoich badań obserwował oraz nagrywał ${ }^{11}$ inwestorów podczas inwestowania online, uzupełniając te dane wywiadami indywidualnymi. Korzystanie przede wszystkim z obsernie wpływa na zachowania inwestujących. wacji, a nie z wywiadów pozwoliło na zmniejszenie ryzyka otrzymywania od badanych racjonalizacji decyzji inwestycyjnych zamiast faktycznego opisu procesu decyzyjnego. Opierając się na zebranych danych, Preda pokazał, że działania inwestorów należy interpretować w kategoriach spotkań (gaming encounters), podczas których inwestorzy wchodzą $\mathrm{w}$ interakcje z innymi - anonimowymi dla nich - partnerami transakcji.

Innym przykładem są badania Daniela Beunzy i Davida Starka (2012), którzy w jednym z banków przez trzy lata prowadzili obserwację (łącznie 60 wizyt) traderów ${ }^{12}$ zajmujących się arbitrażem ${ }^{13}$. Obserwacja ta została uzupełniona o analizę historyczną i wywiady z pracownikami banku. Badani traderzy mieli dostęp do olbrzymich baz danych i modeli wykorzystywanych do ich interpretowania. Jednak podczas badań okazało się, że traderzy, żeby potwierdzić swoje hipotezy oparte na wynikach ich własnych modeli, analizują wykresy cen giełdowych, które traktowali jako odzwierciedlające modele innych uczestników rynku. Jeśli wykresy wskazywały na coś innego niż wynikało to z ich własnych modeli, traderzy przyglądali się jeszcze raz swojemu modelowi, żeby wychwycić ewentualny błąd. Taki mechanizm pozwala na weryfikację własnych modeli i zmniejsza ryzyko popełnienia błędu. Jednak gdy inni aktorzy początkowo korzystają z podobnych modeli i opierają się na podobnych informacjach, to taka sytuacja może doprowadzić do nadmiernego zaufania we własne wnioski i zbiorowej pomyłki, co au-

${ }^{12}$ Osoba zajmująca się krótkoterminowym handlem instrumentami finansowymi.

${ }_{13}$.W żargonie finansowym jest to handel akcjami poszukuący mało ryzykownego zysku opartego na rozbieżnósi cen na przykład cen podobnych aktywów" (MacKenzie 2009: 187 [tłum. własne]). torzy określili mianem rezonansu poznawczego. Przykładem takiego zbiorowego błędu jest niedoszła fuzja GE i Honeywell. Po ogłoszeniu planowanej fuzji, ceny akcji obu firm zachowywały się tak, jakby wszyscy byli przekonani o tym, że fuzja ta dojdzie do skutku. To przekonanie wśród większości inwestorów trwało aż do zablokowania fuzji przez Komisję Europejska, co okazało się bardzo dużym zaskoczeniem dla rynków finansowych. Jednak, jak pokazała analiza doniesień medialnych z tamtego okresu, zablokowanie fuzji przez Unię było wtedy uznawane za prawdopodobne. Umknęło to całkowicie uwadze większości inwestorów, ponieważ wykresy cen wskazywały na realizacje fuzji. Później badani potwierdzili w rozmowach $\mathrm{z}$ badaczami hipotezę rezonansu poznawczego jako wyjaśnienie niedostrzeżenia przez rynki finansowe ryzyka niedojścia fuzji do skutku.

Ostatni z przykładów badań dotyczy handlu algorytmicznego, czyli sytuacji, kiedy komputery na podstawie algorytmów samodzielnie, bez każdorazowej akceptacji przez człowieka dokonują transakcji. Ten rodzaj handlu jest obiektem badań eksploracyjnych prowadzonych przez przedstawicieli nauk społecznych.

$\mathrm{W}$ ramach jednego $\mathrm{z}$ takich badań grupa naukowców pracujących w Wielkiej Brytanii zrealizowała wywiady indywidualne, obserwacje i nieformalne wywiady w miejscach ważnych dla handlu algorytmicznego, uzupełniając te informacje analizą prasy i dokumentów związanych z tą tematyką. Badanie to pokazało, że główne problemy przy handlu algorytmicznym są podobne jak przy tradycyjnym handlu na rynku finansowym (MacKenzie i in. 2012). Autorzy ustalili, że jednym z głównych problemów jest problem sprawiedliwości, szczególnie istotny na 
amerykańskim rynku finansowym, na którym działa duża liczba inwestorów indywidualnych. Do handlu algorytmicznego wykorzystywane są superszybkie komputery, których na pewno nie można określić mianem ogólnodostępnych. Ponadto, pomimo wykorzystania najnowszych technologii komunikacyjnych, odległość również ma znaczenie, ponieważ liczy się każda milisekunda. W 2010 roku pomiędzy dwoma centrami finansowymi Stanów Zjednoczonych, czyli Nowym Jorkiem i Chicago, kosztem 300 milionów dolarów, zbudowany został nowy światłowód, który przyspieszył przepływ informacji finansowych pomiędzy tymi miastami jedynie o 3 milisekundy. Te 3 milisekundy stanowiły na tyle dużą przewagę nad konkurencją, że znalazło się wiele firm gotowych sporo dopłacić za korzystanie z tego łącza. Ponadto nadal aktualny pozostaje inny kluczowy problem problem norm (w tym nieformalnych) i ich przestrzegania. Do tej pory z przestrzeganiem norm przez osoby pracujące na rynkach finansowych bywało różnie, ale czy można mówić o nieformalnych normach na rynku, na którym zarówno pośrednikami, jak i handlującymi są komputery?

Pomimo podobieństwa problemów związanych $\mathrm{z}$ handlem algorytmicznym do tradycyjnych problemów rynków finansowych, autorzy wyciągnęli również bardzo ważny wniosek dla dalszych badań związanych z tematyką handlu algorytmicznego. Zgodnie z założeniami Science and Technology Studies (STS) jest bardzo mało prawdopodobne, że zmiany w materialnej strukturze rynku nie spowodują zmian w relacjach społecznych w ramach tego rynku. Według autorów ta zmiana i jej konsekwencje powinny stanowić ważny przedmiot zainteresowania badaczy społecznych zajmujących się finansami.
Powyższe przykłady pokazują zatem, że postępujące procesy komputeryzacji rynków finansowych nie powodują zbędności perspektywy jakościowych badań społecznych, ale stawiają nowe wyzwania przed osobami badającymi rynki finansowe zgodnie z paradygmatem jakościowym.

\section{Wnioski i implikacje}

Zachodzące procesy określane mianem finansjalizacji powodują, że rynki finansowe wywierają bardzo duży wpływ nie tylko na gospodarkę, ale również bezpośrednio na życie społeczne. Na pierwszy rzut oka - ze względu na domniemaną racjonalność ich profesjonalnych uczestników, anonimowość transakcji, wielość dostępnych danych ilościowych i metod ich analizy - wydaje się, że rynki finansowe nie są odpowiednim przedmiotem badań jakościowych Jednak dotychczasowe rezultaty badań z zakresu tej dziedziny pozwalają na stwierdzenie, że wykorzystanie metod jakościowych może pomóc lepiej zrozumieć mechanizmy działania tych rynków. Można wyróżnić trzy obszary, w których badaniu metody jakościowe udowodniły swoją przydatność i które powinny być przedmiotem dalszych dociekań. Trzeba podkreślić, że obszary te nie są rozłączne - są współzależne i podczas badań jednego obszaru najprawdopodobnie należy poruszyć zagadnienia z dwóch pozostałych Pierwszym $z$ takich obszarów badań jest performatywność ekonomii finansowej. Należy zaznaczyć, że badania tego obszaru wymagają zwrócenia się ku socjologii materialnej i uwzględnienia nie-ludzkich aktorów. Drugim z kluczowych obszarów dla badaczy jakościowych są badania najważniejszych uczestników rynków finansowych, czyli banków i innych firm $\mathrm{z}$ tego sektora. Instytucje te powinny być analizowane z perspektywy takich subdyscyplin jak socjologia czy antropologia organizacji. Trzecim ważnym obszarem badań jakościowych z dziedziny finansów są procesy komputeryzacji i automatyzacji rynków finansowych. Rolą badaczy powinno być opisanie zapośredniczonych przez sieć interakcji z anonimowymi partnerami transakcji oraz wzajemnego wpływu tego, co techniczne (the technical) i tego, co społeczne (the social), co pozwoliłoby na lepsze zrozumienie zachodzących zmian i ich konsekwencji.

Jednak często badaczom społecznym zależy nie tylko na zrozumieniu analizowanych zjawisk, ale również na możliwości wywierania wpływu na rzeczywistość. W tym kontekście osoby zajmujące się badaniami jakościowymi rynków finansowych podobne są do klasyków pragmatyzmu, według których myślenia nie można oddzielać od działania. Jak w swej monumentalnej monografii dotyczącej filozofii współczesnej pisze Tadeusz Gadacz, dla Johna Deweya „poznanie jest instrumentem skutecznego działania, kontroli określonych sytuacji, ustalenia rozwiązań praktycznych problemów" (2009: 335). Jak pokazują życiorysy czołowych prekursorów pragmatyzmu, nie była to dla nich jedynie maksyma epistemologiczna, ale również odnosząca się do wyboru przedmiotu badań i do podejmowania aktywności na rzecz zmiany społecznej. Pierwsi przedstawiciele pragmatyzmu zajmowali się ważnymi wówczas problemami społecznymi i aktywnie uczestniczyli $\mathrm{w}$ życiu publicznym, wychodząc poza debaty odbywające się $\mathrm{w}$ zaciszu gabinetów akademickich (Bauch 2007; Gadacz 2009; Hammington 2014). Na analogiczną potrzebę aktywnego uczestnictwa w życiu publicznym wskazuje czołowy przedstawiciel społecznych badań nad finansami (social studies of finance) Donald MacKenzie (2009), który uważa, że cele naukowców powinny wychodzić poza akademię, a wyniki ich prac powinny służyć również rozwiązywaniu istotnych problemów związanych ze światem finansów ${ }^{14}$. W każdym $\mathrm{z}$ opisanych $\mathrm{w}$ artykule obszarów badacze społeczni mogą dostarczyć wiedzy przydatnej osobom zawodowo zajmującym się rynkami finansowymi - zarówno przedstawicielom firm-uczestników rynku, jak i regulatorom czy projektantom tych rynków. Przykładem badań przydatnych dla praktyków jest artykuł w Harvard Business Review ${ }^{15}$ dotyczący skutecznego wywierania wpływu przez ekspertów od ryzyka na zarządzających (Mikes i in. 2013). Z kolei przykładem praktycznych wniosków dla regulatorów i projektantów rynku jest raport grupy badaczy dla rządu brytyjskiego (Pardo-Guerra i in. 2010). Raport ten był częścią raportu foresight i dotyczył zagrożeń związanych z automatyzacją handlu na giełdzie. Na pewno problemem, przy rozwiązywaniu którego mogą okazać się pomocne wyniki badań jakościowych, jest również potrzeba zmiany kultury organizacyjnej instytucji rynku finansowego ${ }^{16}$.

Powyższy artykuł miał na celu pokazanie, że tak ważny aspekt współczesnego świata jak rynki finansowe nie powinien być ignorowany przez badaczy jakościowych, a perspektywa jakościowych nauk społecznych może przyczynić się do lepszego zrozumienia rynków finansowych oraz dostarczyć wskazówek zawodowo osobom zajmującym się tymi rynkami. ${ }^{14}$ Innym przykładem publikacji, która za cel stawia społecznym
badaniom nad finansami dażenie do przyczynienia się do zmiany na rynkach finansowych, jest np. tekst Forslunda, Baya (2009). ${ }^{15}$ Jest to jedno $z$ najważniejszych (jeśli nie najważniejsze) na świecie pism dla menadżerów.

${ }^{16}$ Miała już miejsce pierwsza publiczna dyskusja na temat kultury banków pomiédzy badaczami, dziennikarzami i przzedsta-
wicielami instytucii finansowych (Panel Discussion. : Challenges wicielami instytucji finansowych (Panel Discussion: Challenges
and Opportunities in Reforming Bank Culture, zob. http://www. and Opportunities in Reforming Bank Culture, zob. http://www.
systemicrisk.ac.uk/events/panel-discussion-challenges-andsystemicrisk.ac.uk/events/panel-discus
opportunities-reforming-bank-culture) 


\section{Bibliografia}

Aalbers Manuel (2008) The Financialization of Home and the Mortgage Market Crisis. "Competition \& Change", vol. 12, no. 2, s. 148166 [dostęp 15 grudnia 2013 r.]. Dostępny w Internecie: http:// openurl.ingenta.com/content//xref?genre=article\&issn $=1024$ $-5294 \&$ volume $=12 \&$ issue $=2 \&$ spage $=148$,

Abolafia Mitchel (1996) Making Markets: Opportunism and Restraint on Wall Street. Cambridge: Harvard University Press.

Arminem Ilkka (2010) Who's Afraid of Financial Markets. „International Sociology", vol. 25, no. 2, s. 1-14.

Austin John (1962) How To Do Things With Words. Oxford: Clarendon.

Bauch Patricia (2007) Jane Addams [w:] Gary Anderson, Kathryn Herr, eds., Encyclopedia of Activism and Social Justice. London: Sage, s. 37-40.

Beunza Daniel, Stark David (2012) From Dissonance to Resonance: Cognitive Interdependence in Quantitative Finance. „Economy and Society", vol. 41, no. 3, s. 383-417.

Callon Michel (1998) Introduction: The Embeddedness of Economic Markets in Economics [w:] tenże, The Lawws of the Markets. Oxford: Blackwell, s. 1-57.

Carruthers Bruce, Stinchcombe Arthur (1999) The Social Structure of Liquidity: Flexibility, Markets, and States. „Theory and Society", vol. 28, no. 3, s. 353-382.

Erturk Ismail i in. (2007) The Democratization of Finance? Promises, Outcomes, and Conditions. „Review of International Political Economy", vol. 14, no. 4, s. 553-575.

Forslund Dick, Bay Thomas (2009) The Eve of Critical Finance Studies. „Ephemera”, vol. 9, no. 4, s. 285-299 [dostęp 15 stycznia 2015 r.]. Dostępny w Internecie: «www.ephemeraweb.org ‘

Gadacz Tadeusz (2009) Historia XX wieku. Nurty. Tom 1. Kraków: Wydawnictwo Znak.

Hall Matthew, Mikes Anette, Millo Yuval (w druku) How Do Risk Managers Become Influential? A Field Study of Toolmaking and Expertise in Two Financial Institutions. „Management Accounting Research”.
Hamington Maurice (2014) Jane Addams [w:] Edward Zalta, Ed, The Stanford Encyclopedia of Philosophy [dostep 15 stycznia 2015 r.]. Dostępny w Internecie: http://plato.stanford.edu/archives/fall2014/entries/addams-jane/.

Ho Karen Zouwen (2009) Liquidated: An Ethnography of Wall Street. Durham: Duke University Press.

Jajuga Krzysztof, Jajuga Teresa (2002) Inwestycje. Instrumenty finansowe, ryzyko finansowe, inżyniera finansowa. Warszawa: $\mathrm{Wy}-$ dawnictwo Naukowe PWN.

Knorr-Cetina Karin, Preda Alex, eds. (2005) The Sociology of Financial Markets. Oxford: Oxford University Press.

----- (2013) The Oxford Handbook of the Sociology of Finance. Oxford: Oxford University Press.

Konecki Krzysztof (2006) Procesualne ujeccie organizacii. Interpretatyrun socjologia organizacji i zarzadzania [w] Krzysztof Konecki, Beata Glinka red., Wspótczesne problemy socjologii organizacji i zarzadzania. Wybrane zagadnienia. Łódź: Wydawnictwo Uniwersytetu Eódzkiego, s. 11-24.

Kovalerchuk Boris, Vityaev Evgenii (2000) Data Mining in Finance. Advances in Relational and Hybrid Methods. New York: Kluwers Academic Publishers.

MacKenzie Donald A. (2006) An Engine, Not a Camera: How Fi nancial Models Shape Markets. Cambridge: MIT Press.

----- (2009) Material Markets: How Economic Agents are Constructed. Oxford, New York: Oxford University Press.

MacKenzie Donald A., Millo Yuval (2003) Constructing a Marke, Performing Theory: The Historical Sociology of a Financial Derivatives

MacKenzie Donald A., Muniesa Fabian, Siu Lucia, eds. (2007) Do Economists Make Markets? On the Performativity of Economics. Princeton: Princeton University Press.

MacKenzie Donald A. i in. (2012) Drilling Through the Allegheny Mountains. ,Journal of Cultural Economy", vol. 5, no. 3, s. 279-296.
Martin Randy (2002) Financialization of Daily Life. Philadelphia: Temple University Press.

Mikes Anette, Hall Matthew, Millo Yuval (2013) How Experts Gain Influence. „Harvard Business Review”, vol. 91, no. 7-8, s. $70-74$.

Pardo-Guerra Juan Pablo i in. (2010) Impersonal Efficiency and the Dangers of a Fully Automated Securities Exchange. „Foresight Driver Review", DR11. Foresight, London [dostęp 13 grudnia 2013 r.]. Dostępny w Internecie: http://www.bis.gov.uk/assets/ foresight/docs/computer-trading/11-1230-dr11-impersonal-eff iciency-and-dangers-of-a-fully-automated-securities-exchan ge.pdf.

Philippon Thomas (2011) The Size of the U.S. Finance Industry: A Puzzle? Federal Reserve Bank of New York [dostęp 7 września 2013 r.]. Dostępny w Internecie: http://www.newyorkfed.org/research/conference/2011/NYAMP/Fed_Philippon_v1.pdf.

Preda Alex (2009a) Framing Finance: The Boundaries of Markets and Modern Capitalism. Chicago: University of Chicago Press.

---- (2009b) Brief Encounters: Calculation and the Interaction Order of Anonymous Electronic Markets. „Accounting, Organizations, and Society", vol. 34, no. 5, s. 675-693.
Sapra Steven G., Zak Paul J. (2008) Neurofinance: Bridging Psychology, Neurology, and Investor Behavior.,.SSRN Electronic Journal" [dostep 13 grudnia 2013 r.]. Dostępny w Internecie: http:// www.ssrn.com/abstract=1323051.

Smith Charles W. (1999) Success and Survival on Wall Street: Understanding the Mind of the Market. Lanham: Rowman \& Littlefield.

Starzeński Oskar (2011) Analiza rynków finansowych. Warszawa C.H. Beck.

Taleb Nassim (2010) The Black Swan. The Impact of the Highly Improbable Unabridged. New York: Random House.

Tarim Emre (2012) A Narrative Approach to Sense-Making in Financial Markets: The Case of the Istanbul Stock Exchange. „SSRN Electronic Journal" [dostęp 10 kwietnia 2013 r.]. Dostępny w Internecie: http://ssrn.com/abstract=2115215,

Zaloom Caitlin (2006) Out of the Pits: Traders and Technology From Chicago to London. Chicago: University of Chicago Press.

Zielonka Piotr (2003) Czym sa finanse behawioralne, czyli krótkie wprowadzenie do psychologii rynków finansowych. „Materiały i Studia" 158 [dostep 20 grudnia 2013 r.]. Dostepny w Internecie http://www.nbp.pl/publikacje/materialy_i_studia/ms158.pdf.

\section{Cytowanie}

Pyfel Łukasz (2015) Badacz jakościowy w światyni liczb i pieniadza - wykorzystanie metod jakościowych w badaniu rynków finansowych. „Przegląd Socjologii Jakościowej”, t. 11, nr 1, s. 70-83 [dostęp dzień, miesiąc, rok]. Dostępny w Internecie: ‘www.przegladsocjologiijakosciowej.org.

\section{Qualitative Researcher in the Temple of Numbers and Money-Using Qualitative Methods in Researching on Financial Markets}

Abstract: This article demonstrates how qualitative research methods can contribute to better understanding of financial markets. At the beginning, the growing importance of financial sector in economy and social life, development of financial markets, and financial research methods are briefly described. Then, examples of qualitative research from three distinguished areas are presented as an illustration of usefulness of qualitative methods in researching on financial markets. These areas are: 1) performativity of economics, 2) researching on financial markets' organizations, and 3) researching on issues connected with computerization and automation of financial markets. The areas at hand should become object of further explorations by qualitative researchers. The final section also contains examples of practical implications of qualitative research and possible directions of practical use of knowledge which is a product of qualitative studies on financial markets

Keywords: sociology of finance, qualitative methods, financial markets, performativity of economics, sociology of organization 